\title{
Maquiavel e a dimensão simbólica do poder: fundamentos da teoria democrática de Claude Lefort
}

Machiavelli and the symbolic dimension of power: the foundations of Claude Lefort's democratic theory

Quando, em 1976, a revista de filosofia Esprit anunciava como o acontecimento mais importante da filosofia contemporânea francesa o "retorno da política", ela indicava uma mudança significativa na reflexão histórica e filosófica de boa parte da intelectualidade daquele país ${ }^{1}$. Obviamente, esse anunciado retorno à política não significava que ela havia sido ausente na produção intelectual anterior. É certo que importantes pensadores franceses do pós-guerra colocavam-se abertamente como partidários de uma filosofia politicamente engajada. A novidade então anunciada se referia ao fato de que numerosos pensadores, antes adeptos de uma concepção da política entendida como epifenômeno da base social, passavam a tomá-la como objeto em si mesmo importante para as análises históricas e filosóficas, fenômeno em torno do qual se constituiria aquilo que se poderia designar como a escola francesa do político ${ }^{2}$.

É professor de Ciência Política da Universidade Federal de Alfenas (Alfenas, MG, Brasil). E-mail: gleytoncst@yahoo.com.br.

Para apontamento e análise das revistas filosóficas relacionadas a esse revival da filosofia política na França, ver Jennings (1997).

2 A expressão "escola francesa do político" é utilizada por Lynch (2010) e pelo próprio Rosanvallon para designar um conjunto de pensadores que se dedicarão à pesquisa política, histórica e filosófica a partir das pistas abertas pelo conceito de "político" desenvolvido por Lefort. Obviamente, isso não significa que não existam controvérsias e desacordos entre aqueles que poderíamos identificar como representantes dessa tendência teórica. É o caso da discordância entre o próprio Lefort e Furet sobre os significados da Revolução Francesa. Para a explicitação de discordâncias entre outros teóricos importantes associados à escola do político, como Gauchet e Abensour, ver Ingram (2006). 
O redirecionamento desses estudiosos em busca de um pensamento sobre o político permitiu a retomada de temáticas antes marginais ou consideradas de menor importância, como o significado da Revolução Francesa para a experiência da sociedade moderna, as implicações políticas do fenômeno religioso e o processo de laicização das sociedades ocidentais. Mais fundamentalmente, essa reorientação alçaria ao centro das investigações a questão da democracia e suas formas de legitimação, paradoxalmente, num momento de crise e contestação da própria experiência democrática. Abandonava-se, dessa forma, a perspectiva de que a política e suas expressões constituíssem fenômenos secundários em relação aos fenômenos sociais em função do reconhecimento da dignidade da política como objeto de estudo.

Quando se trata do pensamento sobre o político, no entanto, não resta dúvida de que Claude Lefort ocupa lugar reconhecidamente central. ${ }^{3}$ Caberia a ele reposicionar decisivamente o tema da democracia e de sua problemática natureza a partir de uma crítica renovada do totalitarismo. Nessa revalorização lefortiana do estudo sobre o político, a influência do pensamento de Maquiavel é, reconhecidamente, fundamental. Vários dos intérpretes de Lefort apontam para a centralidade da concepção maquiaveliana da conflituosidade endêmica de Roma como razão de suas boas leis na releitura lefortiana da democracia como sociedade que institucionaliza o conflito (Abensour, 1994; Flynn, 2005, 2012; Poltier, 1997).

Neste texto, chamo a atenção para a noção de "dimensão simbólica do poder" como elemento fundamental dessa redescoberta do político operada por Lefort a partir da releitura de Maquiavel. É verdade que alguns dos intérpretes de Lefort apontam para o fato de que o termo "simbólico" em sua obra permanece vago e sem uma mais precisa definição (Poltier, 1998, p. 184). Nesse sentido, ele teria permanecido preso à ambiguidade característica desse tema, qual seja a de tomar a dimensão simbólica, ao mesmo tempo, como uma invenção humana e como uma característica inata ao próprio ser (Breckman, 2012, p. 30). ${ }^{4}$ Complexa também é a identificação das fontes e influências lefortianas a respeito deste tema. É possível identificar a influência da antropologia de Mauss, sobre o qual ele se refere como

Para o reconhecimento da centralidade do papel de Lefort no pensamento sobre o político por parte de Rosanvallon e Gauchet, nas palavras dos próprios autores, veja-se Lynch (2010, p. 26).

Para Breckman (2012, p. 34), no entanto, a falta de precisão do conceito de simbólico em Lefort não expressaria sua falta de rigor, mas o fato de que ele não pretenderia restringir-se à noção abstrata de simbólico do estruturalismo. 
um "fenomenologista do mundo social", mas seria possível assinalar também a aproximação do texto lefortiano com a psicanálise de Lacan. ${ }^{5}$ Neste último, interessa, particularmente, a aproximação da concepção lacaniana do modelo de divisão intrapsíquico com a ontologia merleau-pontyana da divisão constitutiva da subjetividade. Assim, a distinção lacaniana entre o simbólico, o imaginário e o real poderia ser integrada à crítica de Merleau-Ponty às filosofias totalizantes por meio da ideia da divisão constitutiva do ser, ainda que a terminologia de Lacan não compareça sempre em sentido preciso nos textos de Lefort. ${ }^{6}$

Neste artigo, destaco o fato de que também em relação à noção da dimensão simbólica do poder a dívida lefortiana com Maquiavel é enorme. Será sob as pistas deixadas pelo secretário florentino que Lefort lançará nova luz sobre a questão democrática e o fenômeno totalitário. A partir de uma concepção propriamente política derivada de Maquiavel, tornar-se-ia possível compreender a mutação de ordem simbólica instaurada pela democracia e pela possibilidade da emergência de seu outro: o totalitarismo.

\section{Maquiavel e a dimensão simbólica do poder}

Em Maquiavel, Lefort encontra, definitivamente, uma reflexão sobre o político que lhe permite renovar a compreensão da democracia e do fenômeno totalitário e que abriria toda uma renovada agenda de pesquisas. À obra do secretário florentino Lefort dedicaria seu volumoso estudo doutoral escrito sob a orientação de Raymond Aron e apresentado no início dos anos de $1970 .{ }^{7}$ Seria impossível analisar detidamente aqui a complexidade temática e estrutural dessa obra verdadeiramente colossal. Interessa-nos, muito mais, reconhecer os elementos da leitura lefortiana de Maquiavel que permitiriam ao autor realizar uma reavaliação da questão democrática a partir da descoberta da dimensão instituinte do político sob o signo do conflito.

A partir de O príncipe, Lefort situa Maquiavel entre as tradições do pensamento político mais influentes de seu tempo. Nesse aspecto, o que chama a atenção do leitor seria o fato de que as reflexões maquiavelianas apontariam para uma nova forma de pensamento em rompimento tanto com os manuais cristãos de governo quanto com os trabalhos clássicos da antiguidade. Dessa

Sobre a influência de Mauss ver Lefort (1990).

Para a discussão sobre o uso do modelo lacaniano por parte de Lefort ver Newman (2004).

Nossa referência é a própria tese (Lefort, 1972). 
maneira, Maquiavel não pensaria os desafios do homem de governo inseridos numa estrutura geral de relações, seja na relação com os sujeitos com os quais deve lidar, seja com a natureza ou com Deus. A condição do príncipe não seria analisada em função de outras formas de organização humana, como Aristóteles faz em relação à família, nem em relação a uma ordem política em analogia com a ordem natural, como Platão realiza ao conceber a tripartição da alma política - noção de ordem natural que também seria utilizada pelo pensamento político cristão, decisivamente elaborado pela escolástica, ao construir a ordem política em analogia com a ordem divina, ao mesmo tempo em que toda autoridade derivaria de Deus. Sobre essas questões, observa Lefort, Maquiavel simplesmente silencia. Isso porque seu pensamento visaria a um novo objeto: a autonomia e a irredutibilidade da política em relação à cosmologia e à teologia.

No entanto, inserida no contexto político de seu tempo, sua desconstrução crítica se projetaria também contra seus contemporâneos ocupados com a rotina diária do poder. Por isso mesmo, essa "lenta e metódica destruição do ensinamento tradicional", realizada pelo criticismo maquiaveliano da tradição, oscilaria entre dois polos. Por um lado, ele pretenderia demolir a concepção clássica e cristã do Estado denunciando a pequena política dos falsos sábios de Florença. Em oposição a eles, substituiria o saber filosófico e cristão por um não saber, "de tal sorte que sua análise do poder parece um momento suspenso no vazio". Por outro lado, no entanto, ele opõe à ignorância dos pragmáticos palacianos satisfeitos com meras intrigas os ensinamentos da história e a exigência da previsão racional da "ordem das coisas", não mais pensada como ordem natural, mas como ordem das relações de força e dos desejos (Lefort, 1972, p. 399-400).

Lefort destaca, no capítulo VI d'O príncipe, a descoberta maquiaveliana fundamental de que a política se dá no campo das aparências e, portanto, de que o poder possui uma dimensão simbólica inescapável. Isso se dá quando Maquiavel afirma que o ato de fundação de uma nova ordem não é um simples produto da vontade soberana do príncipe, uma vez que ele deve imitar a virtude dos grandes homens do passado e, se não possuir tais virtudes, pelo menos parecer possuí-las. Daí a exortação para que os príncipes saibam produzir simbolicamente o significado mítico daquilo que fizeram os grandes fundadores, como Moisés, Rômulo e Remo. A necessidade da repetição ou quase repetição dos feitos dos grandes heróis do passado, não deve, 
portanto, ser confundida com a realização de atos de heroísmo no presente. Como observa Lefort, esse resgate do heroísmo não se inscreve no campo do real, mas no campo do imaginário, a partir do qual uma nova ordem pode ser simbolicamente forjada. Nesse sentido, "somos inclinados a julgar que a figura do herói é puramente simbólica, ou melhor dizendo, que a função realista dos grandes exemplos é uma função simbólica" (Lefort, 1972, p. 363).

Nesse mesmo sentido de desvelamento do papel da aparência e do imaginário na política inscreve-se a leitura lefortiana do capítulo VIII d'O príncipe. Neste, Maquiavel pretenderia avaliar o papel da crueldade e da violência, mais uma vez rompendo com a tradição ao recusar todo critério moral na análise de tal questão. A reflexão maquiaveliana se encaminharia por acentuar a necessidade como critério de avaliação do uso da violência ao mesmo tempo em que faria uma distinção entre o bom e o mau emprego da crueldade. "Sobre o mal é lícito dizer o bem" se a violência é empregada pela necessidade da segurança. A crueldade mal empregada seria aquela que se desenvolve inteiramente sob o signo da violência, enquanto a crueldade bem empregada seria aquela capaz de se modificar em função dos imperativos da relação do príncipe com seus sujeitos. Em contraste com os critérios morais, Maquiavel inscreveria a avaliação da ação do príncipe na dinâmica sempre fluida de suas relações com aqueles que o cercam e influenciam a necessidade de suas ações. Elas estariam, portanto, sempre situadas num contexto social onde adquirem todo seu específico significado. Nesse sentido, o príncipe depende de seus sujeitos que se conduzem em função de uma determinada opinião em relação a ele.

De acordo com Lefort, a reflexão maquiaveliana acentua o fato de que o príncipe só possui existência por meio dos outros, que seu ser está em um fora dele próprio. A própria utilidade da ação do príncipe encontra sua medida no fato de que ela se dá num determinado quadro de relações com outros sujeitos. Nesta situação, o príncipe está condenado sempre a ter de lidar com a representação de sua imagem, com o mundo das aparências de tal forma que, mais importante que o desejo de ser bom é a necessidade de parecer ser bom. Lefort indica, com isto, que Maquiavel "dá a pensar que o poder compreende necessariamente uma mistificação” (Lefort, 1972, p. 413).

O problema da representação é analisado também na leitura lefortiana do capítulo XVIII quando Maquiavel descreve a questão da dissimulação. Sobre essa temática, Lefort aponta o rompimento decisivo do secretário 
florentino com o humanismo clássico quando Maquiavel se recusa a fazer a distinção entre a razão e a paixão, o homem e a besta. Maquivel afirma as duas maneiras de combater, uma pelas leis, própria dos homens, e outra pela força, própria dos animais. Mas como a primeira muitas vezes é insuficiente, torna-se necessário ao príncipe usar a força, comportar-se como um centauro, meio homem, meio animal. Dos animais, seria necessário que o príncipe soubesse reter a força do leão e a simulação da raposa, atributos decisivos ao homem de poder. Lefort faz notar que essa imagem maquiaveliana parafraseia Cícero, para quem as fontes da injustiça, como afirma em seu De offices, estariam exatamente na força e na simulação, uma própria do leão, a outra própria da raposa. Das duas, no entanto, a segunda seria a mais condenável porque "ela dá a aparência de homem de bem quando ele comete o mal" (Lefort, 1972, p. 410), distinção entre o que é próprio do homem e do animal que seria amplamente incorporada pela tradição cristã.

Rompendo com essa distinção clássica, Maquiavel se coloca diante do desafio de conhecer o papel da aparência no mundo da política, o que o encaminha para uma teoria da simulação. Sua concepção seria a de que todo homem é duplo, simulador e dissimulador ao se mover como uma raposa no mundo das paixões. O homem de poder, no entanto, elevaria a outro nível esta duplicidade ao ter de se equilibrar entre governar com as leis, aquilo que é próprio do homem, governar com os dois tipos de animais, o leão e a raposa e, mais ainda, diante do fato de que nunca conseguirá triunfar completamente sobre a dissimulação dos outros homens. Com isto, segundo a leitura lefortiana, Maquiavel poderia visar a compreensão da "verdade efetiva das coisas", mas recusando nesta busca da "verdade" a distinção abstrata convencional entre o verdadeiro e o falso, o real e o imaginário, no sentido de que o imaginário possa ser necessariamente inserido no mundo do real. Lidar com a política, assim sugeriria Maquiavel, envolveria conhecer aquilo que acontece no campo das aparências, do imaginário, mas que influencia o real e oferece uma via de acesso específica a esse real.

Em outro sentido, a importância de Maquiavel para um pensamento pós-marxista, como se pretende o de Lefort, residiria também na importância atribuída à divisão originária do social. A partir da leitura do capítulo nove d'O príncipe, Lefort insiste na importância do desejo no seio da cidade: do lado dos grandes, o desejo de oprimir, de comandar; do lado do povo, o desejo de não ser comandado, de não ser oprimido, ou seja, o desejo de liberdade. 
A leitura lefortiana nota que Maquiavel "abandona espetacularmente as classificações tradicionais onde foram opostos os regimes legítimos e ilegítimos, não corrompidos e corrompidos" para se concentrar na maneira como se dão as lutas de classe, no conflito que habita toda cidade e "se eleva acima da sociedade e a subordina toda inteira à sua autoridade" (Lefort, 1972, p. 381). A ênfase de Lefort sobre a clivagem própria a toda cidade humana é acompanhada pela descoberta da função instituinte do político na relação que entretém com a divisão originária do social. A partir das formas de organização da repartição do poder que regem uma sociedade é que se pode dizer se há sociedade, se há aparecimento do social. Nesse sentido, a manifestação do social reside nesse movimento paradoxal de ameaça de sua dissolução engendrada por suas divisões internas. Maquiavel teria percebido essa questão, problema ao qual todo regime tentaria responder e diante do qual a tipologia dos regimes perderia boa parte de seu sentido.

Toda ordem política, especialmente as novas, teria, portanto, de lidar com o problema da divisão do social. Na leitura lefortiana de Maquiavel, o enfrentamento desse problema se daria na necessidade de forjar a ideia de "povo", recobrindo, com isto, a oposição própria da cidade ao estabelecer uma comunidade aparente ao qual o poder assinala sua identidade. A noção de "povo", nesse sentido, constituiria uma unidade fictícia, uma criação simbólica para garantir uma aparência de unidade estabelecida pela linguagem política. Essa seria das mais difíceis missões do príncipe, uma vez que, por suas ações, ele deverá ser capaz de estabelecer uma transcendência do poder graças ao qual o povo possa se imaginar dentro de uma unidade, mas ao mesmo tempo sujeito à realidade de que a divisão originária jamais encontrará uma solução. Mais uma vez, o príncipe se veria às voltas com a necessidade de estabelecer um imaginário, como efeito de suas boas obras, que torne possível aos homens se reconhecerem. Para Maquiavel, o imaginário político teria a função de recobrir o abismo das disputas entre o povo e os grandes, tornando possível o estabelecimento de sua identidade e a existência do próprio social. Nesse sentido, o homem de poder deveria se instruir da consciência das forças sociais com as quais deve lidar a fim de forjar nelas uma unidade política. "Ao visar a sociedade como um objeto, ele ignora que as classes antagônicas são de natureza diferente, que, incomparáveis nesta, para o Estado a rivalidade implique que eles tenham a mesma identidade e mesmos objetivos" (Lefort, 1972, p. 385). 
Lefort indica nesse diagnóstico maquiaveliano da dinamicidade das sociedades humanas o rompimento do secretário florentino com a tradição aristotélica. Por isso, Maquiavel não oporia à teoria das formas de governo de Aristóteles outra descrição, assim como não pretenderia identificar novos princípios para identificar os governos com base em algum tipo de ontologia. Antes, a diversidade das situações deveria ser pensada nela mesma, e não confrontada com alguma essência capaz de definir aprioristicamente o que é uma situação em conformidade com seus princípios e o que é uma situação degenerada. Na verdade, Maquiavel recusaria encampar um modelo que concebesse um regime político sem defeitos, assim como abriria mão da ideia de moderação como característica de um regime virtuoso. De acordo com Lefort, Maquiavel exortaria o príncipe a se submeter à "política do risco". "O príncipe deve acolher a indeterminação, o que ele justamente o faz, se ele renuncia à ilusão da segurança de um fundamento (...)”. Dessa forma seria possível, para o homem de poder, descobrir "na paciente exploração do possível, os signos da criação histórica, e inscrever no tempo sua ação" (Lefort, 1972, p. 432).

Segundo a leitura lefortiana dos Discorsi, Maquiavel, mais uma vez, subverteria a tradição clássica ao apontar, como a fonte da virtude da República romana, o conflito entre o Senado e a plebe. A grandeza das leis romanas não teria sido simples resultado da clarividência de seus legisladores, mas se alimentado do conflito instaurado na cidade entre a nobreza e a plebe. Nesse aspecto, o modelo romano seria introduzido como elemento desestruturador do modelo espartano de República tão elogiado pelos contemporâneos de Maquiavel. Esparta havia conquistado uma legião de admiradores por combinar três princípios políticos valorizados pela tradição: teria formado um Estado harmonioso, eliminado a discórdia e contornado os efeitos de possíveis acidentes. O exemplo de Roma oferecido por Maquiavel desarticularia o modelo ideal espartano ao demonstrar que a instabilidade, mais que a estabilidade, teria sido a causa principal da glória romana. Nesse sentido, a sensibilidade maquiaveliana apontaria para o fato de que "na desordem mesmo se produz uma ordem; os apetites das classes não são necessariamente maus porque do seu entrechoque pode nascer a potência da cidade" (Lefort, 1972, p. 470).

Lefort nota o fato de que, em conformidade com a tradição clássica, Maquiavel identifica uma das qualidades de Roma na adoção de um regime 
misto. Nesse mesmo sentido, um autor clássico como Políbio teria sido capaz de reconhecer a fecundidade dos eventos acidentais no estabelecimento de boas leis, para além da aposta na ciência do legislador. Como, de resto, aconteceria com a tradição clássica em geral, Políbio teria permanecido preso à ideia de uma essência do Estado vinculado a princípios constituintes. Diferentemente, Maquiavel pretenderia empreender uma análise da história de Roma que requereria novos conceitos. A partir dessa perspectiva pode-se entender, assim indica Lefort, a indiferença maquiaveliana em relação ao tema clássico do homem natural. Isso porque, para o secretário florentino, não faria realmente sentido se referir a um homem fora do Estado político. Somente no espaço da sociedade política faria sentido se interrogar sobre a origem das leis e das condições nas quais elas são criadas e recriadas. A inteligência do problema político encontraria seu movimento, portanto, não nos princípios característicos de cada regime político, mas na dinâmica de contextos sociais concretos cuja tendência é o apetite dos grandes em oprimir. Desse apetite e do desejo do povo em não ser oprimido, desse conflito fundamental, nasceriam as leis que garantem a liberdade. "A desunião, entendemos, não somente preserva a independência de Roma, ela estabelece nela a liberdade, sob um regime tal que o poder não pode ser capturado nem por um homem nem por uma facção" (Lefort, 1972, p. 475). P a r a Lefort, no entanto, Maquiavel não se satisfaria com a tese de que as leis que garantem a liberdade nascem da divisão dos corpos políticos e, a partir do final do quarto capítulo dos Discorsi, argumentaria que a lei da liberdade nasce do desejo do povo. Na disputa entre os grandes e o povo, Maquiavel conduziria seu leitor a tomar parte deste último. No confronto entre as teses aristocráticas e democráticas, Maquiavel se posiciona em favor da última ao fazer notar que o povo, por seu desejo de conservar, é melhor guardião da liberdade que os grandes com seu desejo de adquirir, desejo este, em última instância, insaciável. Nesse sentido, em mais um rompimento com a tradição, Maquiavel indicaria que a ordem da cidade requereria, não a repressão dos desejos dos homens, como afirmariam os conservadores, mas a expansão dos desejos do povo - desejos de liberdade.

De acordo com Lefort, Maquiavel procura demonstrar que a grandeza de Roma ancorava-se em sua capacidade de acolher os conflitos e saber viver no clima tumultuado das opiniões em vez de procurar instaurar a ilusão da estabilidade e da unidade. Esse pensamento, que relaciona divisão e liberda- 
de política, teria como consequência outra concepção sobre a lei, não mais associada à ideia de medida, mas, ao contrário, de desmedida do desejo de liberdade, desejo do povo de não ser oprimido, desejo, portanto, de ser e não de ter. Maquiavel representaria então um pensamento do social sob o signo do conflito, pensamento que se abre à redescoberta do político a partir do reconhecimento da função instituinte do político na relação que mantém com a divisão originária do social. Perceber essa divisão originária do social tem como consequência conceber que é através das formas de organização da repartição do poder que se revela o aparecimento do social, desde sempre ameaçado por sua dissolução - ameaça em relação a qual se institui todo regime político e a qual todo regime procura responder de alguma forma. É aí que se manifesta a divisão do desejo revelada por Maquiavel. Ao mesmo tempo, é no confronto com essa divisão que o social se relaciona com ele próprio, só então aparecendo como tal.

\section{Sobre o real e o simbólico}

Acompanhando a leitura de Maquiavel, é preciso destacar a importância da descoberta lefortiana da dimensão simbólica do político, descoberta a partir da qual sua avaliação da questão democrática será substantivamente enriquecida. Somando-se a essas influências, já o assinalamos, a leitura de Maquiavel indicaria uma concepção da sociedade marcada pelo conflito de tal forma que o poder deveria se representar como algo para além desse conflito endêmica e da pluralidade dos interesses. Dessa forma, Maquiavel permitiria pensar que o poder envolve uma dimensão simbólica da sociedade que não é ancorada no real, mas absorve suas divisões constitutivas, que, permanecendo exterior e não idêntico ao real, torna o mundo social inimaginável sem essa sua referência simbólica. O simbólico dá acesso ao real na medida em que permite a criação da figura da unidade do social e, com ela, do que é legal e ilegal, ao mesmo tempo em que estabelece as categorias ontológicas do existente e do não existente (Breckman, 2012, p. 32). O pensamento lefortiano do político envolve, portanto, em um nível, compreender o papel dos princípios geradores que dão uma forma específica à vida social e, em outro nível, compreender como o político trabalha e organiza a divisão própria do social.

$\mathrm{Na}$ leitura de Lefort, Maquiavel foi capaz de compreender a dimensão simbólica do social como princípio gerador da sociedade para além das con- 
cepções da política entendida como superestrutura das relações de produção. Diferentemente, trata-se de perceber que "é impossível deduzir das relações de produção a ordem da lei, do poder, do saber; é impossível reduzir aos efeitos da divisão capital/trabalho a linguagem em que se articula a prática social”. Na verdade, tais relações “só se desenvolvem em função de condições que não poderíamos colocar no registro do real” (Lefort, 1990, p. 292).

Compreender a complexidade da vida social implicaria, portanto, levar em consideração o real e o simbólico sem pretender reduzir um ao outro. Esse é o sentido da ênfase em examinar os princípios geradores (principes génerateurs) de uma sociedade, ou seja, sua ordem simbólica ou aquilo que Lefort designará como o político, como algo diferente da esfera particular da política. Entre a dimensão simbólica da sociedade e a política se estabeleceria, na verdade, uma complexa relação de identidade e afastamento. Se uma sociedade se organiza em função de determinados princípios simbólicos, torna-se necessário que um determinado agente represente tais princípios invisíveis à sociedade. A resposta lefortiana a esse dilema é o de que a política constitui a instância em que o poder é representado e legitimado, indicando o modo como a sociedade compreende e organiza a si mesma. A política e o poder, portanto, não são algo que se possa simplesmente determinar empiricamente, já que estão desde sempre conectados à representação desses princípios que os legitimam. Daí a ênfase lefortiana de que a essência do poder é tornar visível um modelo de organização na cena política. ${ }^{8}$

Diferentemente daqueles teóricos realistas que pretendem reduzir a sociedade a um conjunto de fatos que deve ser simplesmente espelhado no sistema político, Lefort assume a necessidade de se compreender a realidade social levando em consideração aqueles princípios que ordenam, legitimam, dão sentido e identidade a uma determinada configuração da ordem social. Tais princípios norteariam o modo como se organizam as instituições, assim como a experiência dos indivíduos em suas relações intersubjetivas e com o mundo. Assim, Lefort enuncia que as sociedades se distinguem umas das outras por certa mise en forme, ou seja, por princípios geradores de uma instituição singular do social. Essa mise en forme é acompanhada de uma mise en sens e de uma mise en scéne, ou seja, da instituição de uma experiência específica da coexistência humana e de uma experiência específica de mundo.

A este respeito ver LEFORT, Claude (1990). "A imagem do corpo e o totalitarismo". In: A invenção democrática. São Paulo: Brasiliense. 
Isso não significa afirmar que eles possam ser tomados como fundamento último ou realidade mais profunda a partir do qual a realidade social pudesse ser desvelada. Eles norteiam a realidade social, mas não constituem a realidade social ela própria. Na verdade, Lefort insiste na distinção entre a realidade social e os princípios que a norteiam, ou seja, a distinção entre o real e o simbólico, de tal forma que seria impossível reduzir completamente a complexidade da realidade social a seus princípios, ao mesmo tempo em que essa realidade não pode existir sem referência a eles.

Nesse aspecto, ainda que a democracia tenha aberto novos circuitos para a articulação e realização da autonomia e da realização do homem, o poder democrático, ou mais precisamente, o domínio do poder, permanece no campo daquilo que não pode ser plenamente figurável uma vez que ele está localizado entre o domínio da ação humana e o do indeterminado do ser. Esse caráter indomável da democracia preserva, metaforicamente, algo mistificador, próprio à religião, no sentido de que a imanência do social está sempre obscurecida pelo enigma transcendente de sua própria instituição, assim como o discurso político permanece marcado pela linguagem da teologia. Dessa forma, a autonomia democrática encontra seu limite nesse outro, em um fora, não no sentido de que a instituição do social esteja realmente fora da sociedade, mas no de que a impossibilidade da sociedade ser plenamente realizada a partir de suas próprias representações cria para ela um efeito de exterioridade. Lembremos que Maquiavel já havia se referido à dependência do príncipe em relação a um fora dele mesmo uma vez que está sujeito à imagem que os outros fazem dele. Esse efeito de exterioridade constitui um elemento importante daquilo que Lefort entende como "simbólico". Seria incorreto, portanto, julgar que o poder, numa democracia, estaria dentro da sociedade por emanar do sufrágio popular. Antes, pode-se compreender que o sufrágio popular constitui a instância em que a sociedade é apreendida em sua unidade, mas "essa instância deixou de ter referência em um pólo incondicionado; nesse sentido marca uma clivagem entre o 'dentro' e o 'fora' do social que institui a correspondência entre ambos de maneira puramente simbólica" (Lefort, 1991, p. 32).

Essa representação política, portanto, não significa um mero espelhamento da realidade social, mas a atividade de representar simbolicamente aqueles princípios que organizam a vida social e, por isso mesmo, ela não se dá sem ambiguidade. Nesse aspecto, Lefort aponta para o paradoxo de 
que, se por um lado, a institucionalidade política assim como os discursos e símbolos públicos devem constantemente se referir aos princípios que os legitimam, reforçando diante da sociedade os laços de identidade que os mantém numa determinada ordem, por outro lado, nem o poder nem os atores políticos podem se identificar plenamente com esses princípios, que, na verdade, meramente representam. Isso significa que a realidade social nunca coincide plenamente com os princípios simbólicos que a instituem, ela nunca os realiza plenamente uma vez que permanecem no campo do indeterminável. Diante do fato de que princípios simbólicos como "justiça” ou "igualdade" não poderiam ser definidos de maneira exata, nenhum ator social ou nenhuma instituição pode reivindicar incorporá-los plenamente. Nesse sentido, entre a realidade social e sua dimensão simbólica, há sempre uma diferença, um descompasso que nunca pode ser superado. Por isso mesmo, a sociedade democrática seria marcada por uma radical indeterminação, uma vez que os princípios simbólicos que a instituem caracterizam-se pela abertura a um conjunto de questões que não encontram resposta.

\section{A mutação simbólica da revolução democrática}

Vejamos agora como a descoberta da dimensão simbólica do poder a partir de Maquiavel compõe a agenda de pesquisa em torno da questão democrática por parte de Lefort. Com frequência têm-se observado a dificuldade em classificar a teoria democrática de Lefort, dado o fato de que ela se equilibra entre uma concepção liberal e uma concepção radical da democracia (Weymans, 2005; Ingram, 2006; Geenens, 2008). De fato, Lefort rejeita uma concepção liberal que considere o Estado como garantidor neutro de um consenso razoável originado de um contrato social. Em relação a esse tema, ele continuaria endossando a crítica marxista de que o pretenso Estado neutro liberal mascararia, factualmente, relações de desigualdade, conflito e opressão. Por um lado, portanto, a teoria democrática lefortiana se aproximaria das concepções radicais da democracia ao enfatizar o conflito como constitutivo da própria realidade democrática e como necessário para a manutenção da abertura de suas possibilidades. Nessa perspectiva, o principal perigo para a democracia seria o congelamento dos direitos e de um determinado arranjo institucional que não aceite se colocar à prova do tempo e desafiar seus limites diante do novo. Por outro lado, poderia ser 
aproximado às concepções liberais ao apontar a alienação como um limite necessário à atividade política. Dessa vez, o principal perigo para a democracia seria ultrapassar esse limite, sucumbindo à tentação totalitária de fundir o poder com o social. Essa seria uma visão próxima do liberalismo para quem é necessário acomodar os conflitos políticos no interior de um quadro institucional legal que os estabilizem e os mantenham dentro de uma ordem.

Geenens (2008) observa que, além de se equilibrar entre uma concepção liberal e radical, a obra lefortiana se movimentaria também entre uma justificativa "fraca" e uma justificativa "forte" da democracia. Tal fato poderia ser identificado na variação do tema da indeterminação entre os textos mais antropológicos e antigos de Lefort e seus textos mais recentes que tratam da questão democrática. Na primeira perspectiva, a impossibilidade de determinar a identidade da sociedade é explicada tomando como referência uma estrutura intrínseca à coexistência humana, ou seja, a divisão essencial entre o real e o simbólico, a natureza simbólica do poder e a historicidade das sociedades. ${ }^{9}$ Dessa forma, a convivência social seria desde sempre marcada pela indeterminação, considerada, portanto, uma característica universal aplicável à compreensão de todas as sociedades humanas. Em contraste, numa segunda perspectiva, tratar-se-ia de apontar que especificamente as sociedades modernas seriam expostas à indeterminação como resultado de sua heterogeneidade de valores e opiniões. A fonte da indeterminação seria, portanto, uma experiência específica e historicamente situada nas sociedades modernas e plurais do Ocidente.

Geenens (2008) aponta, nessa variação, uma mudança de ênfase entre os textos mais antigos e os mais recentes de Lefort, o que não chegaria a constituir propriamente uma contradição. A questão fundamental é que, ao indicar que todas as sociedades são históricas e enfrentam a condição inelutável da política, Lefort providencia uma justificativa forte da democracia, uma vez que todo regime político deveria acolher a indeterminação própria de toda sociedade. Noutro sentido, ao afirmar que a indeterminação encontra sua origem na pluralidade das sociedades modernas ocidentais, Lefort oferece uma justificativa fraca da democracia, mais relativista portanto, já que pode-se identificá-la como um regime próprio às condições de sociedades heterogêneas. Dessa forma, em sociedades pré-modernas, muito menos

Para essa concepção ver especialmente Lefort (1979). 
plurais que as ocidentais, seria difícil afirmar que outras formas de governo não democráticos constituem, nesse contexto, um puro e simples erro ou uma incompatibilidade de princípios. ${ }^{10}$

De fato, Lefort não se dedica à realização de uma história da democracia no sentido tradicional, nem a analisar a experiência democrática numa realidade específica. Seu trabalho é muito mais o de reconectar os fios de sentido que tornam possível reconhecer o significado da novidade instaurada pela emergência da sociedade democrática nas pistas abertas pelo pensamento de Maquiavel. Nessa trama, as cidades europeias pré-modernas teriam desempenhado papel importante, embora a democracia não tenha sido resultado específico de suas experiências. A importância do experimento de cidades como Amsterdã e Florença estaria naquilo já identificado pelo historiador Marc Bloch, ou seja, o fato de que essas cidades, desenvolvidas sob o signo da imigração e das trocas comerciais, possibilitaram o contato com a diversidade humana a partir do qual os sinais da igualdade ameaçaram dissolver as hierarquias naturais. "Humanidade singular, corpos estranhos, união dos iguais: estas expressões emergiram da vocação das comunas em tornar-se um fermento de dissolução das ordens hierárquicas que encontraram sua força na Renascença” (Lefort, 2007, p. 1005).

Não coincidentemente, a experiência multicultural de Amsterdã possibilitaria o pensamento de Spinoza, considerado por Lefort o primeiro pensador democrático, assim como em Florença seria permitido a um homem sem título de nobreza, como Maquiavel, tornar-se um ator político privilegiado. ${ }^{11}$ Florença, diferentemente de Veneza, não teria se fechado em algum tipo de oligarquia, mas se mantido aberta ao conflito e à recepção dos imigrantes, novos cidadãos que estabeleceram novas formas de relações sociais e políticas na cidade. De maneira mais geral, portanto, a democracia não poderia ser encontrada simplesmente em um novo tipo de regime, oposto à monarquia, por exemplo. Na verdade, a democracia constituiria certa experiência social, um tipo de sociedade que estabeleceria determinadas condições sociais antes mesmo do nascimento da democracia política.

10 Geenens (2008) nota, no entanto, que mesmo em textos mais recentes Lefort reafirma a universalidade da democracia, como no caso do texto dedicado a Salman Rushdie. Nele, Lefort insiste que não deveríamos aceitar a relativização da imagem do homem completamente absorvido pela comunidade em função da defesa dos direitos humanos entendidos como um modo de existência e coexistência que é propriamente humano.

1 Essas afirmações de Lefort podem ser encontradas em Rosanvallon (2012; p. 6 e 7). 
Com isso, Lefort não quer afirmar que Florença seja a primeira cidade democrática, da mesma forma que Maquiavel não poderia ser qualificado como um pensador democrata. Importa notar em cidades como Florença e Amsterdã o fato de que nelas as hierarquias naturais são ameaçadas de dissolução e, portanto, o fato de que elas experimentaram um conjunto de condições sociais que se tornou terreno fértil para novas possibilidades em vários níveis da coexistência humana. No entanto, faltaria a essas cidades aquilo que também faltaria a Maquiavel e que seria um elemento decisivo na afirmação das sociedades democráticas modernas: a ideia de soberania popular. Nesse aspecto, Lefort afirma que, embora Maquiavel tenha sido o primeiro pensador a conceber com clareza a ideia de povo em termos de identidade nacional, não se encontraria nele o desenvolvimento do princípio da soberania popular. Em O príncipe, o povo apareceria como aquele cuja vontade seria capaz de manter o poder sob controle, constituindo, portanto, um meio de resistência, uma espécie de "contrapoder". Nos Discorsi, por sua vez, o povo apareceria com uma conotação mais positiva, como um fator fecundo para o regime republicano, uma vez que, a partir de sua pressão e de suas demandas, ele se torna um elemento decisivo na determinação das políticas que levam ao bem da República. No entanto, em ambos os casos, não se considera que o povo está no poder, o que significa que o poder não é concebido como algo que ancore sua legitimidade na vontade popular.

É por isso que a experiência decisiva da democracia seria inaugurada pelas grandes revoluções modernas, em especial a Revolução Americana e a Revolução Francesa. Nelas, o povo não figuraria mais como um contrapoder, mas diretamente como aquele do qual o poder emana: por meio da ideia de soberania popular, marca-se uma mudança significativa na ordem simbólica da sociedade que encontraria sua institucionalização no sufrágio universal. Compreender o significado da emergência da democracia envolveria, portanto, observar essa mutação de ordem simbólica que institui os ideais de igualdade e soberania popular como os princípios geradores da sociedade democrática. Dessa forma, o Estado democrático representa esses princípios abstratos do qual retira sua legitimidade sem, no entanto, poder realizá-los plenamente na vida social. Aliás, seria exatamente essa impossibilidade de realizar plenamente os princípios democráticos de igualdade e soberania do povo a garantia da liberdade e da pluralidade. 
O princípio da soberania implicaria uma imagem do povo como Um, uma abstração de unidade diante da realidade da pluralidade social que permite aos indivíduos serem unificados em torno de abstrações como o "Estado Nacional”. Por outro lado, o povo deve ser periodicamente interrogado sobre sua vontade por meio do sufrágio, ou seja, é necessário insistentemente conhecer a vontade de cada um. Assim, torna-se necessário que a sociedade se mobilize, mobilização essa que é a fonte e origem das inúmeras formas de associações e organizações da sociedade democrática. O sufrágio universal possuiria, então, uma dupla dimensão. Por um lado, ele é a consagração da igualdade a partir da qual cada voz e cada argumento valem tanto quanto quaisquer outros. Em sentido diferente, o sufrágio universal existe como um resultado, uma contagem de votos que expressa um resultado num período circunscrito. Em sua dimensão de igualdade, o sufrágio caracteriza a construção de uma forma social que estabelece radicalmente a equivalência da igualdade. Como resultado eleitoral circunscrito de um período, o sufrágio revela as disputas e divisões próprias à sociedade. Por trás dos números dos resultados eleitorais estaria, na verdade, a multiplicidade da sociedade, seus conflitos e a ação política de suas inúmeras associações. ${ }^{12}$

Mas o significado da mutação simbólica que instaurou a democracia só poderia ser plenamente compreendido, na perspectiva lefortiana, no seu confronto com o outro do qual emergiu e com o outro que ela tornou possível emergir. Como já observara Tocqueville, a revolução democrática despontou a partir do interior do Antigo Regime, como um processo de longa duração que não cessou de continuar. A sociedade do Antigo Regime, segundo Lefort, era aquela que representava para si sua unidade, desenvolvida no seio de uma monarquia a partir de uma matriz teológico-política. Essa sociedade era regida pela autoridade do monarca considerado um mediador entre o homem e Deus e, portanto, depositário do sentido da lei e do fim último da ordem social. Ao lado dessa imagem de mediador atribuída ao monarca, apareceu posteriormente outra: a do monarca como soberano já que mediador entre os homens e as instâncias transcendentes figuradas na soberana Justiça e na soberana Razão. Enquanto mediador o príncipe se submetia às leis, enquanto soberano se localizava acima delas. A teoria política do duplo corpo do rei, ao mesmo tempo mortal e imortal, indivi-

12 Ver esta discussão em Rosanvallon (2012), especialmente pgs. 10 e 11. 
dual e coletivo, desenvolvida na Idade Média e estudada por Kantorowicz (1998), fornecia a imagem acabada de um corpo que encarnava o princípio da geração e da ordem do reino, além da própria sociabilidade humana. A sociedade via-se representada num único corpo, figurada no corpo do próprio rei, que retirava seu fundamento de um além do mundo e além do próprio homem. Dessa forma, segundo Lefort, o poder que dava corpo à sociedade do Antigo Regime encontrava-se integrado ao monarca, e, por toda a extensão social, sentia-se a presença de um saber que identificava a todos, colocando-os para ocupar determinado lugar na sociedade. Dessa forma, "o rei conservou o poder de encarnar no seu corpo a comunidade do reino, doravante investida pelo sagrado, comunidade política, comunidade nacional, corpo místico" (Lefort, 1990, p. 117).

Diante do significado atribuído ao Antigo Regime, a revolução democrática constituiria uma novidade porque, em primeiro lugar, dissolveu o fundamento da hierarquia natural. Nesse sentido, segundo Lefort, a revolução democrática explode quando se decompõem a corporeidade do social e o corpo do próprio rei, o que gera uma "desincorporação dos indivíduos". Esse fenômeno remete à intervenção das massas na cena política como número contábil, princípio do sufrágio universal, em oposição à unidade do social. O número decompõe a unidade, dissolve o nome de Um, como diria La Boétie. Por outro lado, afirmar o desaparecimento das hierarquias naturais não significaria dizer que tenham desaparecido as desigualdades sociais. O que aconteceu é que as desigualdades não são mais atribuídas à natureza ou a um direito providencial. De direito os homens nascem iguais, o que implica uma profunda alteração simbólica diante de um regime de matriz teológico-política, alteração a partir da qual o princípio da isonomia deve ser pensado.

Ainda mais, observa Lefort, é preciso notar também a constituição de uma sociedade civil divorciada do Estado a partir da revolução democrática. Isso significa atentar para a emergência de relações sociais, econômicas, jurídicas e científicas que têm seu próprio fim. A revolução democrática, portanto, operaria um "desintrincamento" entre a instância do poder, da lei e do saber, a partir do momento em que se apaga a identidade do corpo político. Assim, se no Antigo Regime o poder encontrava-se incorporado na pessoa do monarca, com a democracia o poder não pode ser mais apropriado por ninguém. O poder se torna um lugar vazio, pois quem o 
exerce só o faz temporariamente e como consequência de uma competição regulada entre grupos e partidos que supõe a liberdade de opinião e associação. Blackwell (2006, p. 57) observa que, na verdade, a ideia de um lugar do poder vazio em Lefort trabalha com uma tensão entre a ausência e a presença no sentido de que o lugar do poder nunca pode ser plenamente vazio. Na verdade, um princípio gerador, como a soberania popular, é vazio do ponto de vista de que não pode ser incorporado por ninguém, mas é presente no sentido de que constitui uma referência simbólica que vincula os cidadãos. "O essencial é que impede aos governantes de se apropriarem do poder, de se incorporarem no poder. Seu exercício depende do procedimento que permite um reajuste periódico" (Lefort, 1991, p. 32). Esse fenômeno implica a institucionalização do conflito e a interdição da cristalização dos conteúdos democráticos.

A partir dessa abertura à incerteza, a sociedade democrática se torna uma sociedade verdadeiramente histórica porque se coloca sujeita à ação do tempo. ${ }^{13}$ A desincorporação do poder, do saber e da lei instaura novas relações sociais, o que significa, segundo Lefort, que a socialização no interior do regime democrático cria domínios de atividades específicos. Assim, o aparecimento dos fatos político, técnico e econômico como fatos autônomos na sociedade abrem a possibilidade para a existência do discurso científico, político e pedagógico com suas normas e conhecimentos próprios.

Enfim, o regime democrático teria instaurado uma verdadeira revolução diante do Antigo Regime ao tornar a divisão constitutiva da própria sociedade e ao dissolver o princípio transcendente de legitimação da ordem social. Nesse aspecto, o trabalho da democracia seria exatamente reconhecer a inevitabilidade da divisão originária que Maquiavel aponta como habitando toda cidade humana. Assim, a comunidade passa a não se reconhecer mais na imagem do corpo, desaparecendo, portanto, a determinação natural de uma hierarquia ligada à pessoa do monarca.

\footnotetext{
Desse ponto de vista, de fato é estranha a análise de Nastrom (2006) segundo a qual Lefort conceberia as sociedades democráticas como aquelas em que a história estaria ausente. Para a autora, como os marcos de certeza foram abolidos na sociedade democrática, isso significaria que ela experimenta um tipo de "tempo vácuo" em que a história não estaria sob nossos olhos. Em decorrência disso, ela conclui que, no entendimento de Lefort, a democracia seria uma sociedade sem história. Basta, no entanto, uma leitura pouco mais atenta aos textos lefortianos sobre Maquiavel e sobre o fenômeno do totalitarismo para constatar o erro da tese da autora. Neles, Lefort é bastante claro ao se referir à sociedade democrática como a sociedade histórica.
} 


\section{A força simbólica do totalitarismo}

No entanto, se por um lado a democracia se mostra como a sociedade aberta ao confronto de suas contradições, por outro lado, afirma Lefort, ela corre sempre o risco de uma petrificação das opiniões e das condutas numa estabilização de seus conteúdos. Isso porque, quando os conflitos se exasperam e a sociedade se conduz ao limite da fratura, o poder que aparece como poder de ninguém corre o risco de ver sua função simbólica anulada. A experiência democrática impõe um mundo de incertezas em que o exercício do poder se faz no seio do conflito. Segundo Lefort, toda vez que a insegurança individual não suporta mais o conflito e a indeterminação constitutivos da democracia, a nostalgia e o desejo de um fundamento último ameaçam desvirtuar a dinâmica democrática. Esse desejo corresponde à paixão pelo corpo coeso, a uma fantástica vontade de apagar o número e recriar a imagem do Um - desejo que é, sobretudo, como diria La Boétie, desejo de servidão. "Com a servidão, o feitiço do nome de Um destruiu a articulação da linguagem política. O povo se quer nomeado (...)”. Mas esse nome que abole a diferença é o do tirano. "O nome destacado, como que vindo de lugar nenhum, como que resumindo tudo em si, torna-se o nome do Outro, do único que tem o poder de falar, longe daqueles que se limitam a ouvir" (Lefort, 1982, p. 146).

Perdendo sua eficácia simbólica, o poder se mostra na sociedade, que se descobre como realidade fragmentada em busca da imagem do povo-uno. É nesse momento que se desenvolve um poder à procura de um corpo social coeso, de um Estado sem divisões que expressaria uma identidade fundamental. "A partir da democracia e contra ela o corpo assim se refaz" (Lefort, 1990, p. 120). O que Lefort quer demonstrar é que a sociedade democrática surge na modernidade como condição para o exercício da liberdade, mas, paradoxalmente, também como portadora das condições de surgimento do totalitarismo.

Na perspectiva lefortiana, portanto, o significado da democracia moderna só adquire contornos claros se contrastado a realidade do totalitarismo. Na compreensão deste, Lefort não se interessa pela singularidade de cada experiência histórica, o que causaria estranhamento a muitos historiadores, mas sim pelo significado propriamente político dessa novidade. Mais uma vez, o fundamental para a compreensão do fenômeno totalitário é a identificação da matriz simbólica assumida pelo poder como apontado por Maquiavel. De acordo com Lefort, a nova forma de sociedade instalada pelo 
totalitarismo, para além das especificidades das histórias nacionais, realizou uma notável concentração das instâncias do poder, da lei e do saber. Dessa forma, o poder pôde se apresentar, pela primeira vez, como o lugar de fato e de direito capaz de definir os fins últimos da sociedade e das normas que devem regular as práticas sociais. $O$ poder se mostra então como o portador de um saber absoluto sobre a história, incorporando-se num partido e em seus dirigentes. Num grau ainda mais elevado de concentração, o poder se confunde com um único homem, a figura do egocrata como descrito por Soljenitsyn, combinando-se a um saber também corporificado em dogmas. Nessa construção em que se condensam os detentores do poder, o saber sobre o futuro da sociedade e as normas reguladoras dessa mesma sociedade, não há espaço para dissenso ou conflito de qualquer espécie.

Entender a novidade instaurada pelo totalitarismo, segundo Lefort, implicaria atentar para a trama das relações que tendem a apagar os traços da divisão social. Nesse processo, o poder afirma-se como o poder social, figurando a própria sociedade de alguma maneira. A linha divisória entre Estado e sociedade civil desaparece ao mesmo tempo em que se dissolve a divisão entre poder político e poder administrativo. Assim, o aparelho do Estado perde toda sua independência diante do partido que representa o governo, tornando-se uma extensão da máquina a serviço das vontades da direção partidária. O poder político circula em todas as esferas da burocracia através dos funcionários do partido e de seus agentes secretos, criando uma relação geral entre o órgão dirigente e os executantes em que estes últimos não possuem a garantia de um estatuto regulador inviolável e, até mesmo, de sua própria existência. Ao mesmo tempo, no topo do partido, o poder passa a ser confundido com a própria figura daquele que detém a autoridade, configurando mais um elemento desse fenômeno que funde Estado e sociedade, poder político e aparelho do Estado. Nesse sentido, por uma inversão da lógica democrática, o poder deixa de se apresentar como um lugar vazio e passa a se materializar num órgão, ou até mesmo num indivíduo, que procura concentrar em si toda a potência da sociedade.

Os critérios últimos da lei e do conhecimento, que na sociedade democrática eram subtraídos ao poder, passam a incorpora-lo novamente. No entanto, essa incorporação se dá de maneira diferente do que ocorria no Antigo Regime. Neste, o poder do príncipe se exercia comandado pela imagem de uma Justiça de origem divina localizada num para além do próprio 
príncipe obrigado, inclusive, a reconhecer direitos adquiridos pela nobreza e pelas cidades. Mesmo nos regimes classificados genericamente como despotismos, nunca o poder se pretendeu como o portador inconteste do princípio da lei e do conhecimento. Para que isso seja possível é necessário que seja demolida toda referência a potências sobrenaturais e que o poder se mascare de forma laica como poder puramente social. É essa, afirma Lefort, a condição fundamental para a emergência da sociedade totalitária e é desse fenômeno puramente moderno que ela retira a força de sua novidade. "O totalitarismo supõe a concepção de uma sociedade que se basta a si mesma e, já que a sociedade se significa no poder, a de um poder que se basta a si mesmo" (Lefort, 1990, p. 83). Nesse sentido, abandonam-se os referenciais tradicionais do absolutismo ou do despotismo, já que a ação e o saber do dirigente não se medem mais por nenhuma força transcendente, mas pelo critério da organização. Da mesma forma, a integridade do corpo social não se remete mais a instâncias de origem divina, mas se mostra a partir da ação e do saber do próprio dirigente. Restabelece-se então a ideia de uma "ordem natural" social, mas que passa a ser suposta como racional, não tolerando divisões e nem fraturas em seu corpo.

Como fundamento desse sistema, Lefort identifica algumas representações que constituem sua matriz simbólica. Em primeiro lugar há que destacar a imagem do povo-Uno, representação de uma sociedade sem fissuras, homogênea e, portanto, reconciliada consigo mesma. Na sociedade soviética frequentemente relacionou-se essa imagem do povo ao proletariado, a classe universal na qual estariam presentes os elementos para a edificação do socialismo e que representaria o povo em sua essência. Combinando-se a essa imagem, e formando duas versões de uma mesma fantasmagoria, emerge a imagem de um poder-Uno. Poder, portanto, concentrado no órgão dirigente e até mesmo num indivíduo que se torna o responsável por encarnar a unidade e a vontade popular. "No fundamento do totalitarismo se alcança a representação do povo-Uno" (Lefort, 1990, p. 112).

A partir de então se torna possível a representação da sociedade como um corpo especializado em suas funções, mas funcionando como uma unidade viva. Como todo corpo vivo, a sociedade passa a defender sua integridade contra aqueles que supostamente seriam seus parasitas. As campanhas de exclusão e perseguição observadas nas sociedades totalitárias evidenciariam essa imagem do corpo social. O inimigo do povo é visto como um dejeto 
a ser eliminado e as campanhas que levam a sua exclusão representam a realização da necessária profilaxia social.

Ao mesmo tempo, a sociedade se mostra como matéria amorfa, como algo a ser organizado pela intervenção incessante do dirigente. Como consequência, o lugar e a função de cada indivíduo nunca estão seguros uma vez que permanecem sempre entregues à ação dirigente do "construtor" social. Afirma-se, então, a fé numa criação sócio-histórica constante, a crença numa edificação permanente da sociedade que justificaria os atos de terror e o sacrifício da geração dos tempos de transição. De acordo com Lefort, essa ideia de uma autocriação da sociedade é acompanhada de uma recusa a toda atividade inovadora que de alguma forma esteja em contraposição a um futuro planejado - futuro já fixado e vislumbrado como a "idade do ouro" para a construção da qual devem se direcionar os esforços de todos os indivíduos. A imagem de uma história que se faz a todo momento seria negada a partir dessa lógica, e tudo o que fosse imprevisível passaria a figurar o inimigo. Representando para si mesma a noção de unidade, a matriz simbólica da sociedade totalitária negaria a divisão originária apontada por Maquiavel como constitutiva de toda cidade.

\section{Considerações finais}

Neste artigo procurou-se destacar a importância da leitura de Maquiavel para o esforço de Lefort em renovar metodologicamente o estudo do político e dos fenômenos contemporâneos da democracia e do totalitarismo. Nesse esforço de renovação metodológica se insere a retomada lefortiana da filosofia política pensada como instrumento que, antes da naturalização de seu objeto, estaria interessada em desvendar os mecanismos que engendram o social histórico e o tornam fato, se dirigindo, portanto, a seu momento instituinte. Dessa forma, o retorno à filosofia política é apresentado por Lefort como o caminho para um conhecimento que pensa o momento de instituição do social. Desse ponto de vista, e tomando como referência a dimensão simbólica característica de toda sociedade, não se trata de estabelecer uma linha divisória entre o que é o político e o que é o social. Lefort definirá o político como o conjunto de procedimentos a partir do qual emerge a ordem social, indicando que político e social são, na verdade, indissociáveis, derivando do primeiro a forma, significado e realidade assumidos pelo segundo. 
Como se procurou destacar, fundamental nessa perspectiva lefortiana foi sua descoberta da "dimensão simbólica do poder" a partir da leitura de Maquiavel. Foi o secretário florentino aquele quem apontou para o fato de que a política se dá no campo das aparências e, portanto, de que o poder possui uma dimensão simbólica inescapável. Pensador do conflito, Maquiavel ensinou que o político constitui-se intersubjetivamente e que, portanto, todo homem público está desde sempre na dependência de um fora dele próprio, já que ancorado na representação de sua imagem diante de outros. Em outros termos, Maquiavel daria a pensar que o poder envolve certa mistificação, uma representação de si mesmo que forja uma ordem no mundo.

Foi com base nessa concepção propriamente política da sociedade que se tornou possível compreender as novidades instauradas pela novidade da democracia e de seu outro, o totalitarismo. Nesse aspecto, antes de se constituírem como regimes políticos, eles se constituiriam como verdadeiros tipos sociais originados a partir de determinadas matrizes simbólicas que, se não são o real, moldam e instituem vias de acesso a esse real. Assim, a emergência da democracia poderia ser pensada a partir da instituição simbólica de seus princípios geradores, as ideias de igualdade e soberania popular, assim como a emergência do totalitarismo poderia ser relido a partir de sua imagem do corpo coeso. Sem uma concepção que coloque no centro de sua análise o fenômeno do político restaria obscura a compreensão de realidades tão decisivas na conformação do mundo contemporâneo.

Nesse sentido, a abertura de toda uma agenda de reflexões e pesquisas possibilitadas pela leitura lefortiana de Maquiavel nos dá a entender que este permanece como um clássico que, mesmo entendido em seu contexto histórico e social, ainda assim nos interroga sobre nossas preocupações e nossos desafios no mundo contemporâneo.

\section{Referências}

ABENSOUR, Miguel (1994). "Reflexões sobre as duas interpretações do totalitarismo em C. Lefort”. Kriterion, n. 90, p. 83-125.

BLACKWELL, Mark (2006). "Lefort and the problem of democratic citizenship". Thesis Eleven, n. 87, p. 51-62.

BRECKMAN, Warren (2012). "Lefort and the symbolic dimension". Constellations, v. 19, n. 1, p. 30-36. 
FLYNN, Bernard (2005). The philosophy of Claude Lefort: interpreting the political. Illinois: Northwerstern University Press.

(2012). "Lefort as phenomenologist of the political". Constellations, v. 19, n. 1, p. 16-22.

GEENENS, Raf (2008). "Democracy, human rights and history: reading Lefort”. European Journal of Political Theory, n. 7, p. 269-286.

INGRAM, James (2006). “The politics of Claude Lefort's political: between liberalism and radical democracy”. Thesis Eleven, n. 87, p. 33-50.

JENNINGS, Jeremy (1997). "The return of the political? New French journals in the history of political thought". History of Political Thought, n. 18, p. 148-156.

KANTOROWICZ, Ernst H. (1998). Os dois corpos do rei: um estudo sobre teologia política medieval. São Paulo: Companhia das Letras.

LEFORT, Claude (1972). Le travail de l'oeuvre Machiavel. Paris: Gallimard. (1979). As formas da história: ensaios de antropologia política. São Paulo: Brasiliense.

(1982). “O nome de Um”, em LA BOÉTIE, Étienne. Discurso da servidão voluntária. São Paulo: Brasiliense.

(1990). A invenção democrática: os limites do Totalitarismo.

São Paulo: Brasiliense.

(1991). Pensando o político. São Paulo: Paz e Terra

(2007). Le temps present. Paris: Belin.

LYNCH, Christian (2010). "A democracia como problema: Pierre Rosanvallon e a escola francesa do político", em ROSANVALLON, Pierre. Por uma história do político. São Paulo: Alameda.

NASSTROM, Sofia (2006). "Representative democracy as tautology: Ankersmit and Lefort on representation". European Journal of Political Theory, n. 5, p. 321-342.

NEWMAN, Saul (2004). "The place of power in political discourse". International Political Science Review, n. 25, p. 138-156.

POLTIER, Hughes (1997). Claude Lefort: la decouvert du politique. Paris: Michalon.

(1998). Passion du politique: la pensée de Claude Lefort. Genève: Labor et Fides.

ROSANVALLON, Pierre (2012). "The test of the political: a conversation with Claude Lefort”. Constellations, v. 19, n. 1, p. 4-15. 
WEYMANS, Win (2005). "Freedom through political representation: Lefort, Gauchet and Rosanvallon on the relationship between state and society". European Journal of Political Theory, n. 4, p. 263-282.

\section{Resumo:}

O presente artigo pretende apontar a influência decisiva da obra de Maquiavel na construção da teoria democrática de Claude Lefort. Em especial, pretende-se assinalar como Lefort assimila de Maquiavel uma concepção propriamente política da sociedade ao identificar na obra maquiaveliana uma noção da "dimensão simbólica do poder". Na perspectiva deste artigo, é a partir dessa noção, que remete à divisão originária e ao momento instituinte do social, que Maquiavel, mesmo não se constituindo como um autor propriamente democrático, permitiria a Lefort uma reavaliação da questão democrática e do fenômeno totalitário.

Palavras chave: simbólico, poder, político, democracia.

\section{Abstract:}

This article points to the decisive influence of Machiavelli's work in building Claude Lefort's democratic theory. In particular, it notes how Lefort assimilates from Machiavelli a properly political conception of society, by identifying in the work of Machiavelli a notion of 'symbolic dimension of power.' According to this article, it is from this concept, which refers to the original division and the instituting moment of the social, that Machiavelli, even though he is not exactly a democratic author, would allow Lefort to reassess the question of democracy and the totalitarian phenomenon.

Keywords: symbolic, power, political, democracy.

Recebido em 31 de maio de 2013.

Aprovado em 20 de agosto de 2013. 